\title{
EKSPRESI PD-L1 PADA MENINGIOMA
}

Raudatul janah*, Lantip rujito**, Daniel Joko Wahyono***

* Mahasiswa Program Doktor Imu Biologi, Fakultas Biologi, UNSOED, Purwokerto/Laboratorium

Patologi Anatomi Rumah Sakit Mata Cicendo, Bandung

** Laboratorium Biologi molekuler dan genetika Fakultas Kedokteran UNSOED Purwokerto

*** Laboratorium Biologi molekuler dan genetika Fakultas Biologi UNSOED, Purwokerto

\begin{abstract}
ABSTRAK
Meningioma merupakan tumor yang paling umum terjadi pada sistem saraf pusat (SSP), berasal dari sel meningothelial lapisan arakhnoid. Programmed Death Ligand 1 (PD-L1) merupakan protein immune checkpoint yang akan menyebabkan imun antitumor tersupresi. Pada meningioma high grade, sel T regulator dan ekspresi PD-L1 meningkat yang disebabkan karena immunosuppressive tumor microenvironment sehingga tumor menjadi agresif. Tingkat ekspresi PD-L1 tidak ditetapkan dalam meningioma. Tergantung pada tingkat ekspresi, anti-PD-L1, mungkin merupakan pengobatan yang efektif untuk meningioma.

Kata Kunci : meningioma, PD-L1, Anti PD-L1
\end{abstract}

\section{ABSTRACK}

Meningiomas are the most common tumors of the central nervous system (CNS), origin from the arachnoid layer of meningothelial cells. Programmed Death Ligand 1 (PD-L1) is an immune checkpoint protein that will cause suppressed immune antitumor. In high grade meningiomas, regulator $T$ cells and $P D-L 1$ expression increase due to immunosuppressive tumor microenvironment so that the aggressive tumor. The extent of $P D-L 1$ expression is not established in meningiomas. Depending on the degree of expression, anti-PD-L1, might be an effective treatment for meningiomas. Keyword: Meningioma, $P D-L 1$, anti-PD-L1

\section{Korespondensi:}

1. dr. Raudatul Janah, Sp.PA

Mahasiswa Program Doktor Imu Biologi, Fakultas Biologi, UNSOED, Purwokerto /

Lab PA RS Mata Cicendo Bandung

Jl. Cicendo no 4 bandung

Hp. 087837356528

E-mail : raudatul.janah1@gmail.com

2. Dr. dr. Lantip Rujito, Msi.med

Kampus FK Unsoed

Jl. Dr. Gumbreg, Mersi, Kec. Purwokerto Tim., Kabupaten Banyumas, Jawa Tengah 53112

Email : rujitoku@yahoo.com

3. Dr. Daniel Joko Wahyono, M.Biomed.

Kampus Fakultas Biologi, Unsoed

Jl. dr. Suparno 63, Karangwangkal, Purwokerto 53122

Email : danieljokowahhyono13@gmail..com 


\section{PENDAHULUAN}

Meningioma adalah jenis tumor yang tumbuh dari membran pelindung otak, yang disebut meninges, yang melapisi otak dan medulla spinalis. ${ }^{1}$ Meningioma muncul dari sel araknoidal leptomeninges dan dapat terjadi di mana saja terutama di bagian sel arachnoid. Insiden meningioma di Amerika serikat sebanyak 7,44 kasus untuk setiap 100.000 penduduk. ${ }^{2}$ Pada tahun 2017 , prevalensi kejadian meningioma di Amerika Serikat lebih banyak terjadi pada wanita yaitu sebanyak 8,44 per 100.000 jiwa dibandingkan dengan laki laki sebanyak 3,76 per 100.00 jiwa. Meningioma dapat terjadi pada pasien usia berapapun dengan puncak decade 6 kehidupan. ${ }^{2}$ Menurut World Health Organizaton (WHO), meningioma dibagi menjadi tiga derajat, yaitu grade I, II, dan III. Meningioma grade I bersifat benign, kurang agresif dan rekurensi rendah berbeda dengan meningioma grade II dan III. ${ }^{3}$

Overekspresi Programmed Death Ligand 1 (PD-L1) pada beberapa tumor disebabkan karena tumor tersebut melindungi dirinya dari serangan sel T sitotoksik. ${ }^{4}$ PD-L 1 merupakan protein immune checkpoint yang akan menyebabkan imun antitumor tersupresi..$^{5}$ Efek imunosupresi sel tumor terhadap kemampuan immune surveillance disebabkan oleh adanya ekspresi PD-L1, yang menghasilkan aksis PD-1/PD-L1 dimana bertemunya PD-1 di sel T dengan ligandnya atau dengan kata lain PD-L1 di sel tumor ini disebut sebagai immune check point. Adanya ikatan PD-1 dengan ligandnya menyebabkan respon dan aktivasi sel T dihambat melalui mekanisme induksi proliferasi, apoptosis dan diferensiasi sel T regulator juga akan menghambat respon imun. ${ }^{6,7}$

Pemeriksaan ekspresi imunohistokimia PD-L1 ditemukan pada Meningioma high grade, karsinoma gaster, pankreas, dan lymphoma sel T.8 Penulisan artikel ini ditujukan untuk mengetahui ekspresi PD-L1 pada meningioma.

\section{PEMBAHASAN}

\section{Meningioma}

Meningioma merupakan tumor yang paling umum terjadi pada sistem saraf pusat (SSP), berasal dari sel meningothelial lapisan arakhnoid.3,9 Di Amerika dan Korea insidensi meningioma merupakan tumor otak yang paling sering sekitar $36 \%$ dan 37,3\%.3,10 Sesuai dengan data Global Cancer Observatory (GLOBOCAN) International Agency for Research on Cancer (IARC) tahun 2012, yaitu $34 \% .{ }^{11}$ 
Meningioma bisa terjadi pada semua umur lebih sering pada dewasa, dengan decade puncak ke 5 kehidupan. Perbandingan kejadian meningioma antara perempuan dan laki-laki yaitu $2: 1 .{ }^{11}$

Menurut WHO (2016) Classification of Tumour of the Central Nervous System, Meningioma diklasifikasikan sesuai dengan tabel 1 yang dibagi menjadi tiga grade, yaitu grade I, II, dan III. ${ }^{3}$ Lokasi meningioma paling sering ditemukan di intrakranial, intraspinal, dan orbita, sedangkan di intraventrikular dan epidural jarang ditemukan (Gambar 1). Sebesar 98\% kasus merupakan meningioma SSP, dimana lokasi paling umum di SPP adalah cerebral convexities (paling sering di parasagital), sphenoid ridges, para-/suprasellar, olfactory groove, optic nerve sheath, petrous ridges, tentorium, dan fossa posterior. ${ }^{12,13}$

Kelainan sitogenetik meningioma yang paling umum adalah perubahan kromosom 22 monosomi dimana kehilangan allelic 22q12 pada gen neurofibromatosis-2 (NF-2) yang mengkode protein merlin, biasanya ditemukan pada meningioma yang sporadik sekitar $40 \%-80 \%$. Perubahan sitogenetik lain yaitu delesi kromosom 1p (prognosis buruk) dan kehilangan kromosom 6q, 9p, 10q, $14 \mathrm{q}$ dan $18 \mathrm{q}$ (high grade). Chromosomal gains pada 1q, 9q, 12 q, 15 q, 17 q dan 20 q pada grade II. 12

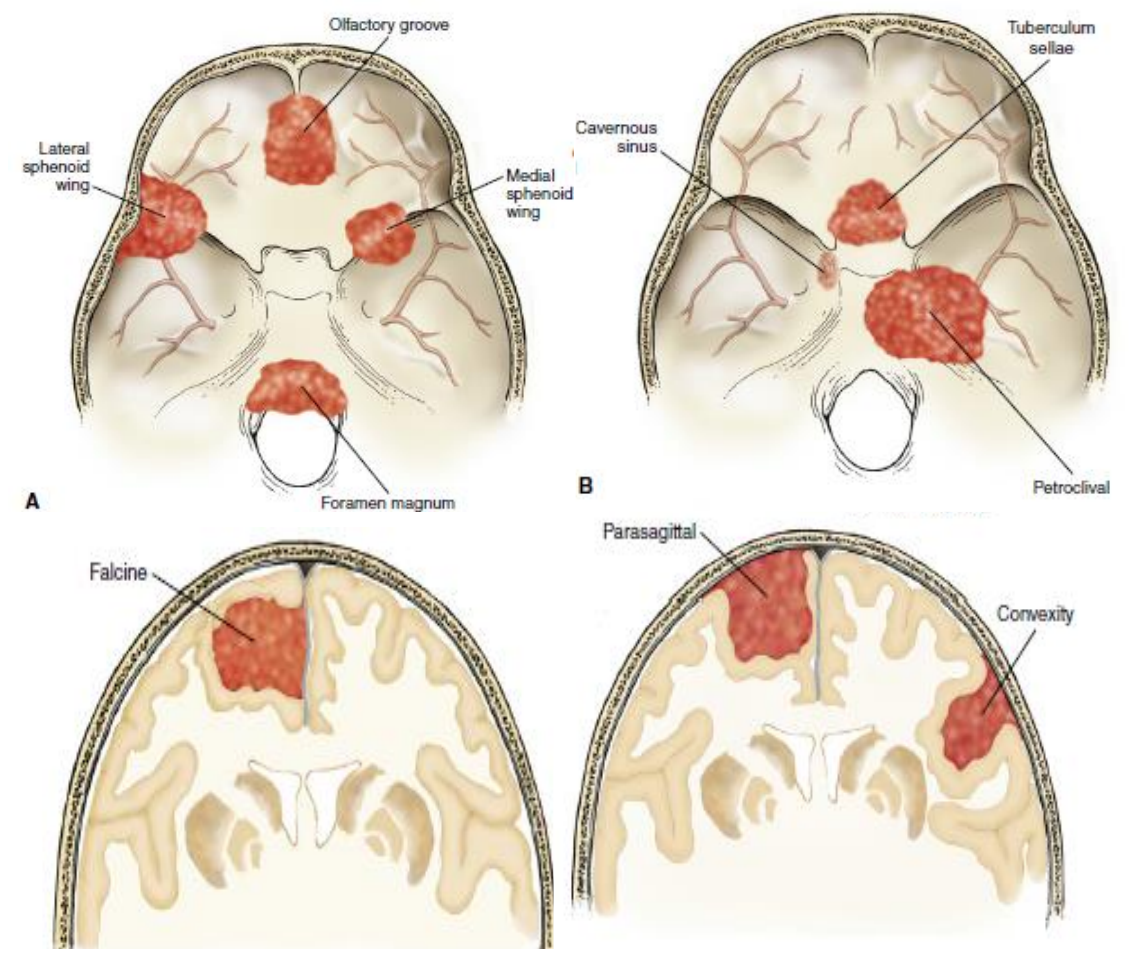

Gambar 1 Lokasi umum meningioma: A. Meningioma Falcine B. Meningioma Parasagital ${ }^{14}$ 


\begin{tabular}{|c|c|c|c|c|}
\hline $\begin{array}{l}\text { WHO } \\
\text { grade }\end{array}$ & Frekuensi & Fitur Patologis & Histologi & $\begin{array}{c}\text { Angka } \\
\text { Rekurens }\end{array}$ \\
\hline Grade I & $80 \%-90 \%$ & $\begin{array}{l}\text { Pleimorfik; bentuk umumnya mitotic; tidak } \\
\text { ada kriteria meningioma anaplastik atau } \\
\text { atipikal }\end{array}$ & $\begin{array}{l}\text { Meningotelial, psammomatous, sekretori, } \\
\text { fibroblastic, angioma, kaya limfoplasmasit, } \\
\text { transisional, mikrositik, metaplastik }\end{array}$ & $7 \%-20 \%$ \\
\hline Grade II & $5 \%-15 \%$ & $\begin{array}{l}\geq 4 \text { bentuk mitotic setiap } 10 \text { lapang } \\
\text { pandang; tiga hal berikut: (a) peningkatan } \\
\text { selularitas, (b) sel kecil dengan rasio N:C } \\
\text { tinggi, (c) nukleoli jelas, (d) perkembangan } \\
\text { seperti lapisan,(e) netosis; invasi otak }\end{array}$ & Sel jelas, kordoid, atipikal & $30 \%-40 \%$ \\
\hline Grade III & $1 \%-3 \%$ & $\begin{array}{l}\geq 20 \text { bentuk mitotic setiap } 10 \text { lapang } \\
\text { pandang atau bentuk anaplastik jelas }\end{array}$ & Papillari, rabdoid, anaplastik & $50 \%-80 \%$ \\
\hline
\end{tabular}

\section{Tabel 1. Grading WHO 2016 dan rekurensi. ${ }^{3}$}

\section{Programmed Death Ligand 1 (PD-L1)}

Programmed death 1 (PD-1, CD279) adalah protein transmembran tipe I yang terdiri dari 288 asam amino dan mengkode gen Pdcd 1 pada kromosom 2q37 manusia. PD-1 terekspresi setelah terjadinya aktivasi sel $\mathrm{T}$ atau sel $\mathrm{B}$, dan adanya antigen yang persisten akan menstimulasi tingginya imunoekspresi PD-1. Fungsi PD-1 sebagai reseptor yang diekspresi dengan aktivasi sel T. Terdapat 2 ligand PD-1, yaitu PD-L1 (B7-H1 atau CD274) dan PD-L2 (B7-DC atau CD 273). 15,16,17,18,19,20

PD-L 1 adalah protein immune checkpoint yang menyebabkan supresi imun antitumor. PD-L1 adalah protein transmembran yang mengkode gen CD 274 pada kromosom 9 manusia yang diekspresikan pada sel tumor dan terutama memberikan efek immunosuppressive PD-1. Tumor yang overekspresi PD-L1 adalah tumor yang melindungi dirinya dari serangan sel T sitotoksik. ${ }^{4}$ Imunoekspresi PD-L1 ditemukan pada sel T, sel B, sel dendritik, makrofag dan sel punca mesenkim. PD-L2 berfungsi untuk menghambat aktivasi sel T. 15,16,17,18,19

PD-L1 terekspresi pada sel tumor, tetapi dapat juga ada pada permukaan sel lain seperti sel T, sel B, sel dendritik, makrofag, sel stem mesenkim, epithelial, sel endothelial dan lemak coklat. ${ }^{21}$ PD-L2 
terekspresi pada APC. PD-L1 terekspresi dengan adanya stimulasi sitokin interferon $\mathrm{Y}$ (IFN $\mathrm{Y}$ ) yang disekresikan oleh sel T yang teraktivasi. ${ }^{21}$

PD-1 dan ligandnya PD-L1 dikenal sebagai molekul penghambat yang menyebabkan terganggunya respon imun melawan sel tumor. ${ }^{21}$ Fungsi PD-L1 dan PD-1 sebagai supresor imun fisiologis yang terhadap respon sel T dan mencegah autoimunitas. Overekspresi PD-L1 ditemukan pada tipe tumor yang bervariasi dan berhubungan dengan prognosis buruk. ${ }^{22}$

\section{PD-L1 pada Meningioma}

PD-L1 terekspresi pada derajat tinggi meningioma, yang diduga mempunyai peranan signifikan terhadap sifat agresif tumor. Programmed cell death protein -1 (PD-1) ialah reseptor permukaan sel pada sel T dan mengikat PD-L1 pada antigen presenting cells (APC) dan sel tumor untuk menghambat aktivasi sel T. Antibodi secara langsung melawan aksis PD-1/PD-L1 yang memperkuat respon imun. Tumor yang overekspresi PD-L1 adalah tumor yang melindungi dirinya dari serangan sel T sitotoksik. ${ }^{23}$ Terjadinya efek imunosupresi oleh sel tumor terhadap kemampuan immune surveillance disebabkan karena sel tumor mengekspresikan PD-L1 sehingga terjadi aksis PD-1/PD-L1 yaitu bertemunya PD-1 di sel T dengan ligandnya yaitu PD-L1 di sel tumor yang disebut sebagai immune check point. Hal ini menyebabkan sel T sitotoksik menjadi anergi. ${ }^{24}$ Keadaan imunoresistensi ini menyebabkan sel T sitotoksik tidak dapat melawan sel tumor sehingga menunjukkan sifat yang agresif. Hal ini berhubungan dengan derajat histopatologi yang lebih tinggi. ${ }^{25,26}$

Penelitian Du dkk menyatakan bahwa meningioma derajat II dan III menunjukkan imunoekspresi terhadap PD-L1. Meningioma dengan riwayat radioterapi juga menunjukkan imunoekspresi PD-L1. Penelitian Du dkk menyatakan bahwa pada meningioma derajat tinggi terjadi immunosuppressive tumor microenvironment yang akan meningkatkan sel T regulator dan menstimulasi PD-L1 yang menunjukkan sifat yang agresif. ${ }^{24}$ 


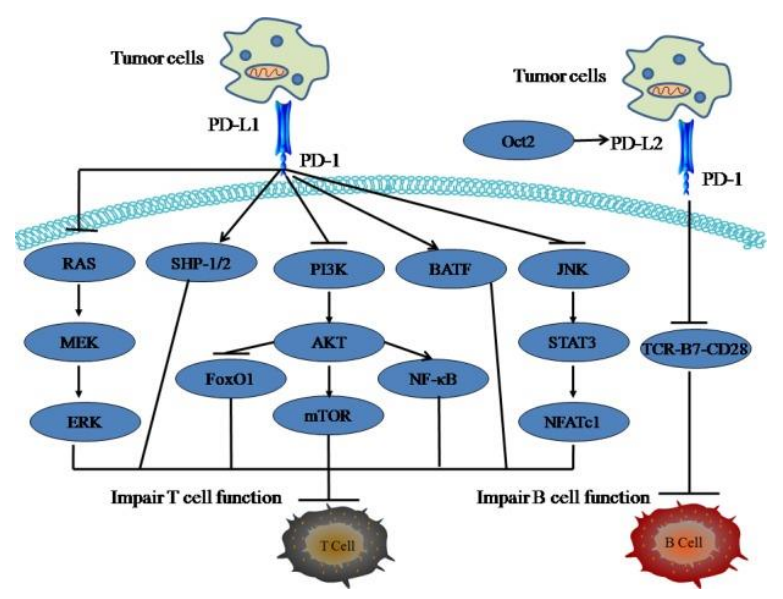

Gambar 2. Interaksi PD-1 dengan PD-L1 dan PD-L2 menyebabkan fungsi sel T dan sel B terhambat ${ }^{35}$

PD-1 berfungsi untuk menghambat aktivasi sel T tidak hanya dengan melemahkan pensinyalan TCR (SHP-1/2), tetapi juga dengan meningkatkan ekspresi gen yang merusak fungsi sel T. Sinyal PI3K-Akt-mTOR, JNK, dan Ras-MEK-ERK adalah regulator penting untuk efek penghambatan yang dimediasi oleh PD-1 pada kekebalan sel T. PD-L2 terutama diekspresikan pada sel B. Oct2 dapat mengatur ekspresi gen PD-L2 dalam sel B-1 dan pada konsentrasi antigen yang rendah, interaksi PD-L2-PD-1 menekan fungsi sel B dengan menghambat sinyal TCR-B7-CD28 (Gambar 2). ${ }^{35}$

Penelitian ini menunjukkan bahwa PD-L1 berhubungan dengan grade meningioma. Imunoekspresi PD-L1 tinggi pada derajat histopatologi yang lebih tinggi. Pada meningioma grade I tampak ekspresi lemah PD-L1 sebesar 77\% dan ekspresi kuat sebesar 23\%. Pada meningioma grade II ditemukan ekspresi lemah PD-L1 sebesar 27\% dan kuat sebesar 73\%. Pada meningioma grade III, ditemukan ekpresi lemah PD-L1 sebesar $13 \%$ dan ekspresi kuat sebesar $87 \%$. Hal ini sejalan dengan penelitian Du dkk yang menunjukkan bahwa ekspresi kuat PD-L1 ditemukan pada meningioma grade II dan III. Penelitian Du dkk juga menunjukkan ekspresi tinggi pulasan IHK PDL-1 grade I 39.1\%, grade II 60.5\% dan grade III 88.9\%. Pada penelitian Du dkk menyatakan bahwa pada meningioma high grade terjadi immunosuppressive tumor microenvironment yang akan meningkatkan sel T regulator dan menstimulasi PD-L1 yang menunjukkan sifat yang agresif. ${ }^{27}$

PD-L1 berhubungan dengan grade meningioma. PD-L1 merupakan faktor yang paling kuat mempengaruhi grade meningioma. Penelitian Du dkk menunjukkan meningioma grade memengaruhi immunosuppressive tumor microenvironment yang akan meningkatkan sel T regulator dan meningkatkan ekspresi PD-L1 yang menunjukkan sifat agresif tumor. ${ }^{11}$ Peningkatan sel FOXP3+ dengan ekspresi tinggi 
PD-L1 diduga terjadi modulasi tumor sebagai respon adaptive immune yang menyebabkan interaksi PD-L1 dan PD-1 yang mempromosikan diferensiasi sel T menjadi sel T regulators. ${ }^{24}$

\section{Imunoterapi anti-PD-1/PD-L1}

Hal-hal yang mendukung peranan imunoterapi pada meningioma, yaitu: tumor merekruit populasi imun, terutama monosit dan sel T sitotoksik, dengan meningkatnya jumlah makrofag terdapat pada tumor derajat tinggi; sebagian besar mutasi yang ditemukan pada meningioma diprediksikan terjadi neoantigenik yang ditemukan lebih banyak pada tumor derajat tinggi; meningioma terjadi di luar sawar darah otak dan dimodulasi oleh respon imun sistemik; dan meningioma derajat tinggi dengan ekspresi marker imun PD-L1 berhubungan dengan prognosis yang buruk, luasnya reseksi dan riwayat rekuren. ${ }^{28}$

Imunoterapi menjanjikan dan telah diteliti sejak 5 tahun terakhir. Penelitian laporan kasus Gerstein menunjukkan penggunaan imunoterapi (anti PD-1/anti PD-L1) ini dapat menurunkan ukuran tumor pada meningioma. ${ }^{29}$ Uji klinis terbaru menunjukkan anti PD-1 atau PD-L1 menyebabkan regresi tumor pada tumor paru non small cell, melanoma, renal cell carcinoma dan Hodgkin Lymphoma. ${ }^{30}$ Saat ini imunoterapi anti-PD-1 yang digunakan adalah Nivolumab. Uji klinis fase II dalam evaluasi blockade checkpoint PD-1 dengan nivolumab untuk meningioma derajat II/III. ${ }^{12}$

Imunoterapi anti-PD-1 nivolumab telah diteliti uji klinis fase III pada pasien dengan glioblastoma rekuren dan fase II pada meningioma. Peranan imunoterapi pada meningioma karena berasal dari luar sawar darah otak yang mengenai sistem limfatik sinus dural, yang mengekspresikan tumor associated antigen yang meningkatkan level PD-L1 pada tumor derajat tinggi. Ekspresi protein PD-L1 yang tinggi pada imunohistokimia (IHK) menunjukkan prediktif biomarker terhadap respon imunoterapi. ${ }^{31}$ Ekspresi level tinggi PD-L1 dapat berhubungan dengan prognosis yang buruk pada meningioma dan dapat dipertimbangkan dampak signifikan terhadap terapi anti PD-1/PD-L1. ${ }^{28}$ Respon imunoterapi berhubungan dengan level ekspresi PD-L1 dan terapi kurang efektif pada meningioma yang kurang ekspresi PDL1. $32,33,34$

Modulasi Immune checkpoint sebagai strategi terapi menarik perhatian lebih dalam terapi kanker. Studi pra-klinis dan uji klinis telah mengkonfirmasi bahwa antibodi anti-PD-1 / PD-L1 memiliki potensi antitumor dan meningkatkan kelangsungan hidup pasien kanker. Saat ini, terapi anti-PD-1 atau anti-PD- 
L1 sedang dalam studi individu dan dalam kombinasi dengan terapi lain seperti kemoterapi sitotoksik, agen antiangiogenik dan inhibitor tirosin kinase. ${ }^{35}$

\section{KESIMPULAN}

1) Tumor merekruit populasi imun, khususnya monosit dan sel $T$ sitotoksik, dengan tingginya konsenterasi makrofag terdapat pada tumor derajat tinggi.

2) Sebagian besar mutasi yang ditemukan pada meningioma diprediksikan terjadi neoantigenik yang jumlahnya lebih tinggi pada tumor derajat tinggi.

3) Meningioma terjadi di luar sawar darah otak dan dimodulasi oleh respon imun sistemik.

4) Meningioma derajat tinggi dengan ekspresi marker imun PD-L1 berhubungan dengan prognosis yang buruk, luasnya reseksi dan riwayat rekuren. ${ }^{12}$

\section{DAFTAR PUSTAKA}

1. Roser, F. 2004. The Prognostic Value of Progesterone Receptor Status in Meningiomas. J Clin Pathol; 2004: 57 (10): 1033-1037.

2. Ongaratti, B R et al. 2016. "Expression of Merlin, NDRG2, ERBB2 , and c-MYC in Meningiomas : Relationship with Tumor Grade and Recurrence." 49: 4-9.

3. David N. Hiroko OO, Wiestler Webster, Cavenee. Meningioma. WHO Classification of Tumours of the Central Nervous System. Fourth Edition e. Lyon: International Agency for Research on Cancer; 2016. p. 231-44.

4. Hashem O. Alsaab SS, Rami Alzhrani, Katyayani Tatiparti,, Ketki Bhise SKK, danArun K. Iyer. PD-1 and PD-L1 Checkpoint Signaling Inhibition for Cancer Immunotherapy: Mechanism, Combinations, and Clinical Outcome. 2017.

5. Edwin R. Parra, Pamela Villalobos, Barbara Mino,dan Jaime Rodriguez-Canales. Comparison of Different Antibody Clones for Immunohistochemistry Detection of Programmed Cell Death Ligand 1 (PD-L1) on Non-Small Cell Lung Carcinoma. Wolters Kluwer Health. 2017.

6. Ioannis Zerdes AM, Jonas Bergh, George Z. Rassidakis, Theodoros. Genetic, transcriptional and post-translational regulation of the programmed death protein ligand 1 in cancer: biology and clinical correlations. Oncogene. 2018:1-23.

7. Anthousa Kythreotou AS, Francesco A Mauri, Mark Bower, David J Pinato. PD-L1. 2017.

8. Chang JGKSLTMC-C. Programmed Death Ligand-1 (PD-L1) Expression in the Programmed Death Receptor-1 (PD-1)/PD-L1 Blockade. Arch Pathol Lab Med. 2017; Vol 141.p.1-11.

9. B. K. Kleinschmidt-DeMasters FJ, Rodríguez, Tarik Tihan. Meninges. Diagnostic Pathology Neuropathology. Canada: Elsevier; 2016. p. 450-67.

10. Yun Sik Doh KWJ, Johyun Ha, . An Updated Nationwide Epidemiology of Primary Brain Tumors in Republic of Korea, 2013. 2017.

11. RE. H. Epidemiology of Brain Tumour. Global Epidemiology of Cancer. USA: Cenveo Publisher Service; 2016. p. 393-402.

12. Wenya Linda Bi1 WWW, Sandro Santagata,David A Reardon \& lan F Dunn. Checkpoint inhibition in meningiomas. 2016.

13. Richard G. Ellenbogen LNS, Neil D. Kitchen. Convexity and Parasagital Versus Skull Base Meninigoma. Principle of Neurological Surgery.Fourth Edition. Philadelphia: Elsevier; 2018. p. 593-601. 
14. Arie Perry DJB. Meningiomas. Practical Surgery Neuropathology A Diagnostic Approach. China: Elsevier; 2010. p. 185-215.

15. McDermott MWdD. Targeting PD-1/PD-L1 in the treatment of Metastatic renal cell carcinoma. Therapeutic Advances in Urology. 2015.p.1-13.

16. Kurzrock SPPaR. PD-L1 Expression as a Predictive Biomarker in Cancer Immunotherapy American Association for Cancer Research 2015.

17. Chang JGKSLTMC-C. Programmed Death Ligand-1 (PD-L1) Expression in the Programmed Death Receptor-1 (PD-1)/PD-L1 Blockade. Arch Pathol Lab Med. 2017;Vol 141.p.1-11.

18. McDermott MWaD. Targeting PD-1/PD-L1 in the treatment of metastatic renal cell carcinoma. Sage journal. 2015.p.1-13.

19. Yi Que WX, Yuan-xiang Guan, Yao Liang, Shu-Mei Yan. PD_L1 Expression is associated with FOXP3+ Regulatory T-cell infiltration of Soft Tissue Sarcoma and Poor Patient Prognosis. Journal of Cancer. 201723. Hashem O. Alsaab SS, Rami Alzhrani, Katyayani Tatiparti,, Ketki Bhise SKK, danArun K. lyer. PD-1 and PD-L1 Checkpoint Signaling Inhibition for Cancer Immunotherapy: Mechanism, Combinations, and Clinical Outcome. 2017.

20. Xia Fang, Bing Xiu,, Zhizhang Yang, , Weizhe Qiu, , Long Zhang, ,Suxia Zhang,dkk. The expression and clinical relevance of PD-1,PD-L1, and TP63 in patients with diffuse large B-cell lymphoma. 2017.

21. Ioannis Zerdes AM, Jonas Bergh, George Z. Rassidakis, Theodoros. Genetic, transcriptional and post-translational regulation of the programmed death protein ligand 1 in cancer: biology and clinical correlations. Oncogene. 2018:1-23.

22. Shiyang Wang BL, Seema Patel, Jeffrey S. Weber, Travis J. Hollmann, Matija Snuderl,dkk. Programmed death ligand 1 expression and tumor infiltrating lymphocytes in neurofibromatosis typ (Anon., n.d.)e 1 and 2 associated tumors. Journal of Neuro-Oncology. 2017:1-8.

23. Hashem O. Alsaab SS, Rami Alzhrani, Katyayani Tatiparti,, Ketki Bhise SKK, danArun K. Iyer. PD-1 and PD-L1 Checkpoint Signaling Inhibition for Cancer Immunotherapy: Mechanism, Combinations, and Clinical Outcome. 2017.

24. P Momtaz PM. Immunologic Checkpoints in cancer therapy: focus on the Programmed Death-1 (PD-1) receptor pathway. Pharmacogeneomics and personalized medicine. 2014:357-65.

25. Ziming Du MA AAA, Allison R. McHenry, Heather, H. Sun, Mark-Anthony Bray, Omar Viramontes, Revaz Machaidze, dkk. Increased expression of the immune modulatory molecule PDL1 (CD274) in anaplastic meningioma.2014.

26. Marco B. Schaaf ADGdPA. Defining the role of the tumor vasculature in antitumor immunity and immunotherapy. Springer. 201878. Manuel A. Silvav KAR, Claudia Wilm , Jenifer Caldara, Hans Juergen Grote, dan Janet C. Patterson-Kane. PD-L1 immunostaining scoring for non-small cell lung cancer based on immunosurveillance parameters. Plos One. 2018.

27. Anthousa Kythreotou AS, Francesco A Mauri, Mark Bower, David J Pinato. PD-L1. 2017.

28. Wenya Linda Bi1 WWW, Sandro Santagata,David A Reardon \& Ian F Dunn. Checkpoint inhibition in meningiomas. 2016.

29. Haneen Imran ETR, Hira Arshad Jawed, Areeba Nisar, Usama Khalid Choudry dan, kumar A. Antibody Targeted Therapies in Meningiomas: A Critical Review. Journal of Surgery and Emergency Medicine.2017.

30. Patrick A. Ott FSH, dan Elizabeth I. Buchbinder Inhibition of immune checkpoints and vascular endothelial growth factor as combination therapy for metastatic melanoma: an overview of rationale,preclinical evidence, and initial clinical data. Frontiers in Oncology. 2015.

31. Hui Yu TAB, Caicun Zhou, David L. Rimm, Fred R. Hirsch. PD-L1 Expression in Lung Cancer. IASLC. 2016.

32. Richard W. Joseph MP, Jeanette E. Eckel-Passow, Dan Serie , Kevin Wu , Liuyan Jiang,, Krishna Kalari RHT,dkk. Validation of an inverse association between programmed death ligand 1 (PDL1) and genes in the vascular endothelial growth factor (VEGF) pathway in primary clear cell renal cell (ccRCC). Cancer Imunology Research. 2013.

33. Song Xue MH, Veena lyer and Jinming Yu. Blocking the PD-1/PD-L1 pathway in glioma: a potential new treatment strategy. Journal of Hematology and Oncology. 2017:1-10. 
34. Marco B. Schaaf ADGdPA. Defining the role of the tumor vasculature in antitumor immunity and immunotherapy. Springer. 201878. Manuel A. Silvav KAR, Claudia Wilm , Jenifer Caldara, Hans Juergen Grote, dan Janet C. Patterson-Kane. PD-L1 immunostaining scoring for non-small cell lung cancer based on immunosurveillance parameters. Plos One. 2018.

35. Xinbing Sui, Junhong Ma, Weidong Han, Xian Wang, Yong Fang, Da Li,Hongming Pan, dkk. The anticancer immune response of anti-PD-1/PD-L1 and the genetic determinants of response to anti-PD-1/PD-L1 antibodies in cancer patients Oncotarget. 2015 Aug 14; 6(23): 19393-19404. 